\title{
Defects in insulin signal transduction in liver and muscle of pregnant rats
}

\author{
M .J . A . Saad, L. M aeda, S. L . B renelli, C.R . O. Carvalho, R .S. Paiva, L. A . Velloso \\ Laboratory of Cellular and M olecular Biology, D epartment of Internal M edicine, FCM - U NICA M P, Campinas, Sao Paulo, B razil
}

Summary Pregnancy is known to induce insulin resistance, but the exact molecular mechanism involved is unknown. In the present study, we have examined the levels and phosphorylation state of the insulin receptor and of insulin receptor substrate 1(IRS-1), as well as the association between IR S- 1 and phosphatidylinositol 3-kinase (PI 3-kinase) in the liver and muscle of pregnant rats (day 20 of gestation) by immunoprecipitation and immunoblotting with anti-insulin receptor, anti-IR S-1, anti-PI 3-kinase and antiphosphotyrosine antibodies. There were no changes in the insulin receptor concentration in the liver and muscle of pregnant rats. H owever, insulin stimulation of receptor autophosphorylation, as determined by immunoblotting with antiphosphotyrosine antibody, was reduced by $30 \pm 6 \% \quad(p<0.02)$ in muscle and $36 \pm 5 \% \quad(p<0.01)$ in liver at day 20 of gestation. IRS-1 protein levels decreased by $45 \pm 6 \%$ $(p<0.002)$ in liver and by $56 \pm 9 \% \quad(p<0.002)$ in muscle of pregnant rats. In samples previously immunoprecipitated with anti-IR S-1 antibody and blotted with antiphosphotyrosine antibody, the insulin-stimulated IR S-1 phosphorylation levels in the muscle and liver of pregnant rats decreased by $70 \pm 9 \%$ $(p<0.01)$ and $75 \pm 8 \%(p<0.01)$, respectively. The insulin-stimulated IR S-1 association with PI 3-kinase decreased by $81 \pm 6 \%$ in muscle $(p<0.01)$ and $79 \pm 11 \% \quad(p<0.01)$ in the liver during pregnancy. These data suggest that changes in the early steps of insulin signal transduction may have a role in the insulin resistance observed in pregnancy. [D iabetologia (1997) 40: 179-186]

Keywords Insulin resistance, pregnancy, insulin action, insulin receptor, insulin receptor substrate, PI 3-kinase.
Insulin resistance during pregnancy has been reported both in women and in experimental animals [1-7], but the mechanism of this resistance remains unclear. In vivo studies have shown that pregnant rats become progressively resistant to insulin after day 16 of gestation [5]. In these animals, the insulin resistance of skeletal muscle has been clearly

R eceived: 3 A pril 1996 and in revised form 5 N ovember 1996

Corresponding author: M.J.A. Saad, M.D., D epartment of Internal M edicine, FCM , U NICA M P, Cidade U niversitária Zeferino Vaz, Campinas, SP, B razil 13081-970

A bbreviations: IR S-1, I nsulin receptor substrate 1; PI 3-kinase, phosphatidylinositol 3-kinase; SD S-PA GE, sodium dodecylsulfate-polyacrylamide gel electrophoresis; PMSF, phenylmethylsulfonylfluoride; BSA, bovine serum albumin. demonstrated in vitro, while the insulin resistance in vivo in peripheral tissues and liver has been substantiated in studies using the euglycaemic-hyperinsulinaemic clamp technique $[6,7]$.

Insulin initiates its metabolic and growth-promoting effects by binding to the $\alpha$ subunit of its tetrameric receptor, thereby activating the kinase in the $\beta$ subunit [8]. This interaction catalyses the intramolecular autophosphorylation of specific tyrosine residues of the $\beta$ subunit which further enhances the tyrosine kinase activity of the receptor toward other protein substrates [8]. In most cells, this primary event leads to the subsequent tyrosyl phosphorylation of a cytoplasmic protein with an apparent molecular weight of 160-185 kDa, called insulin receptor substrate 1 (IR S-1) [9-11]. Considerable evidence indicates that insulin receptor tyrosine 
kinase and the associated IR S-1 phosphorylation are essential for many of the biological effects of insulin [12-16]. IR S-1 is also phosphorylated in response to insulin-like growth factor-1, interleukin-4 and angiotensin II [8-11, 17, 18] and, following its phosphorylation, it can associate with proteins containing Src homology 2 (SH 2) domains through specific tyrosyl phosphorylation sites [19, 20]. In cells in culture and in animal tissues, phosphorylated IRS-1 associates with the lipid metabolizing enzyme phosphatidylinositol 3-kinase (PI 3-kinase) thereby activating the enzyme [21-23]. The insulin receptor, IR S-1 and PI3-kinase therefore represent three of the earliest steps in insulin action, and each of these can be demonstrated and regulated in two of the main target tissues for the metabolic actions of insulin in vivo, namely liver and muscle [24-26].

The role of the phosphorylation of IR S-1, the endogenous substrate for the insulin receptor, and its association with $\mathrm{PI}$ 3-kinase in the insulin resistance of pregnancy are not known. In the present study, we have investigated the phosphorylation state of the insulin receptor and IR S-1, as well as the association of the latter with PI 3-kinase in the liver and muscle of pregnant rats stimulated with insulin.

\section{Materials and methods}

Materials. Reagents for sodium dodecyl sulfate-polyacrylamide gel electrophoresis (SDS-PA GE) and immunoblotting were from B io-R ad (R ichmond, Calif., U SA ). Tris, phenylmethylsulfonylfluoride (PM SF), aprotinin, dithiothreitol (DTT), Triton X-100, Tween 20, glycerol and bovine serum albumin (BSA, fraction V) were from Sigma Chemical Co. (St. L ouis, M o., USA ). Protein A -Sepharose 6 MB was from Pharmacia (U ppsala, Sweden), [ ${ }^{125}$ ] ]protein $A$ was from A mersham (A ylesbury, UK) and nitrocellulose paper (BA 85, $0.2 \mathrm{~mm}$ ) was from Schleicher $\&$ Schuell (K eene, N.H., U SA). Sodium amobarbital (A mytal) and human recombinant insulin ( $\mathrm{H} \mathrm{um}$ ulin R) were from Eli Lilly Co. (Indianapolis, Ind., USA). Monoclonal antiphosphotyrosine antibody and anti-PI 3-kinase antiserum was from UBI (Lake Placid, N.Y., USA). A nti-insulin receptor antibody and anti-IRS-1 antibodies were raised in rabbits using a synthetic peptide derived from the amino acid sequence to the $\mathrm{C}$-terminus of these proteins and were kindly provided by D rs. C.R. K ahn and M.F. White (Joslin D iabetes Center, B oston, M ass., USA ).

\section{M ethod}

A nimals and tissue extracts. E ight-week-old female Wistar rats were mated. O ne group of 24 pregnant rats (day 20 of gestation) and age-matched non-pregnant rats were allowed access to standard rodent chow and water ad libitum. The animals were studied after 7-8 $\mathrm{h}$ of fasting. The studies were performed in parallel using control (virgin) and pregnant rats in each pair. A II experiments involving animals were approved by the U niversity of Campinas E thical Committee.

The rats were anaesthetized with sodium amobarbital (15 mg/kg body weight, i. p.) and used as soon as anaesthesia was assured by loss of the pedal and corneal reflexes. The abdominal cavity was opened, the portal vein exposed, and $0.5 \mathrm{ml}$ of normal saline $(0.9 \% \mathrm{NaCl})$, with or without $10^{-5}$ $\mathrm{mol} / \mathrm{l}$ insulin, was injected. Thirty seconds later, the livers were removed, minced coarsely and homogenized immediately in approximately 10 volumes of solubilization buffer $A$ in a water bath maintained at $100^{\circ} \mathrm{C}$ using a Polytron PTA $20 \mathrm{~S}$ generator (model PT 10/35, B rinkmann Instruments, Westbury, N.Y., USA) operated at maximum speed (setting 10) for $30 \mathrm{~s}$. The solubilization buffer $A$ was composed of $1 \%$ SD S, $100 \mathrm{mmol} / /$ Tris ( $\mathrm{pH}$ 7.4), $100 \mathrm{mmol} / \mathrm{l}$ sodium pyrophosphate, $100 \mathrm{mmol} / \mathrm{l}$ sodium fluoride, $10 \mathrm{mmol} / \mathrm{EDTA}$, and $10 \mathrm{mmol} / \mathrm{l}$ sodium vanadate. The homogenate was then boiled for a further $10 \mathrm{~min}$ and then cooled in an ice bath for $40 \mathrm{~min}$.

A pproximately $90 \mathrm{~s}$ after insulin injection, hindlimb muscles were excised and homogenized with a Polytron in 6 volumes of homogenization buffer $A$ at $100^{\circ} \mathrm{C}$. The extracts were centrifuged at $55000 \mathrm{rev} / \mathrm{min}$ at $4^{\circ} \mathrm{C}$ in a Beckman $70.1 \mathrm{Ti}$ rotor (Palo A Ito, Calif., USA) for $60 \mathrm{~min}$ to remove insoluble material, and the supernatant was used as the sample. In some experiments, the tissues were extracted at $4^{\circ} \mathrm{C}$ with homogenization buffer B (same as buffer A except that $1 \%$ Triton $X-100$ replaced $1 \%$ SDS and $2 \mathrm{mmol} / \mathrm{PMSF}$ and $0.1 \mathrm{mg}$ of aprotinin $/ \mathrm{ml}$ were added), and after centrifugation the supernatant was used for immunoprecipitation with anti-IR S-1 antibody and Protein A -Sepharose 6 MB or protein A /G plus (Santa Cruz Technology, Santa Cruz, Calif., U SA ).

The insulin dose employed in this study was based on previous work in which the amount of insulin required to achieve a significant signal was determined $[23,24]$. Thus, we know that a bolus injection of $10^{-5} \mathrm{~mol} / \mathrm{l}$ insulin via the portal vein will lead to a transient rise in the peripheral concentration 5-10 times the postprandial levels at $90 \mathrm{~s}$. The very high levels of insulin reached suggest that different levels of insulin cannot explain some of the variation observed.

P rotein analysis by immunoblotting. The samples were treated with Laemmli sample buffer [27] containing $100 \mathrm{mmol} / \mathrm{l}$ DTT and heated in a boiling water bath for $4 \mathrm{~min}$. For total extracts, similar sized aliquots ( $150 \mu \mathrm{g}$ of protein) were subjected to SD S-PA GE ( $6 \%$ tris-acrylamide) in a B io-R ad miniature lab gel apparatus ( $M$ ini-Protean, $B$ io- $R$ ad). The electrotransfer of proteins from the gel to nitrocellulose was performed for $2 \mathrm{~h}$ at $120 \mathrm{~V}$ (constant) using a B io-R ad miniature transfer apparatus ( $M$ ini-Protean) as described by Towbin et al. [28] but with $0.02 \%$ SD S added to the transfer buffer to enhance the elution of high molecular mass proteins. Non-specific protein binding to the nitrocellulose was reduced by preincubating the filter overnight at $4{ }^{\circ} \mathrm{C}$ in blocking buffer (3\% BSA, $10 \mathrm{mmol} / \mathrm{l} \mathrm{Tris,}$ $150 \mathrm{mmol} / \mathrm{l} \mathrm{N} \mathrm{aCl}$, and $0.02 \%$ Tween 20). The prestained $\mathrm{M}_{r}$ standards were myosin ( $205 \mathrm{kD}$ a), $\beta$ galactosidase (116 kD a), ( $80 \mathrm{kD}$ a), and ovalbumin (49.5 kD a).

The nitrocellulose blot was incubated for $4 \mathrm{~h}$ at $22^{\circ} \mathrm{C}$ with antiphosphotyrosine antibody, anti-insulin receptor antibody, anti-IRS-1 antibody, anti-PI 3-kinase antibody or antiSH PTP2 antibody (Santa Cruz Technology) diluted in blocking buffer; then washed for $60 \mathrm{~min}$ in blocking buffer without $B S A$. The blots were then incubated with $2 \mu \mathrm{Ci}$ of [125 ] protein A $(30 \mu \mathrm{Ci} / \mu \mathrm{g})$ in $10 \mathrm{ml}$ of blocking buffer for $1 \mathrm{~h}$ at $22^{\circ} \mathrm{C}$ and washed again as described above for $2 \mathrm{~h}$. [ ${ }^{125} \mathrm{I}$ ] Protein $\mathrm{A}$ bound to the antibodies was detected by autoradiography using preflashed Kodak X A R film (E astman Kodak, R ochester, N.Y., USA ) with Cronex Lightning Plus intensifying screens (D uPont, Wilmington, D.E., USA) at $-70^{\circ} \mathrm{C}$ for $12-48 \mathrm{~h}$. B and intensities were quantitated by optical densitometry (model GS 300; Hoefer Scientific Instruments, San Francisco, Calif, USA ) of the developed autoradiogram. 
$O$ ther assays. Protein determination was performed by the $B$ radford dye-binding method [29] using the $B$ io- $R$ ad reagent and BSA as the standard. The plasma glucose concentrations were measured by the oxidase method. Plasma insulin levels were measured by double-antibody radiommunoassay (D iagnostic Products Corp., L os A ngeles, Calif., USA ). Some animals in both groups were also submitted to an insulin tolerance test $\left(0.5 \mathrm{ml}\right.$ of $10^{-5} \mathrm{~mol} / /$ insulin, i. v. $)$ and samples for plasma glucose determination were collected at 0 (basal) , 4, 8, 12 and 16 min after insulin injection. The rate constant for plasma glucose disappearance ( $\mathrm{K}$ itt) was calculated using the formula $0.693 / t_{1 / 2}$. The plasma glucose $t_{1 / 2}$ was calculated from the slope of the least square analysis of the plasma glucose concentrations during the linear decay phase.

Statistical analysis. Experiments were always performed by analysing samples from the pregnant rats in parallel with a control group. For comparisons, Student's unpaired t-test was used. The level of significance was set at $p<0.05$.

Results

A nimal characteristics. Fasting plasma glucose concentrations were lower in pregnant than in virgin rats $(5.16 \pm 0.27$ vs $6.16 \pm 0.22 \mathrm{mmol} / \mathrm{l}, \mathrm{p}<0.02)$ and fasting serum insulin concentrations were higher in pregnant rats than in virgin rats $(2.78 \pm 0.28$ vs $1.94 \pm 0.14 \mathrm{pmol} / \mathrm{l}, \mathrm{p}<0.02)$. Thus, the serum insulin concentration was inappropriately high for the low plasma glucose concentrations in pregnant rats [insulin-to-glucose ratio ( $\mathrm{pmol} / \mathrm{mmol}$ ) 53.8 in pregnant rats vs 31.4 in virgin rats]. In order to demonstrate that the pregnant rats were insulin resistant, the animals were submitted to an insulin tolerance test. The glucose disappearance rate during this test was lower in pregnant than in virgin rats (pregnant $2.24 \pm 0.84$ vs virgin $4.84 \pm 0.3 \% / \mathrm{min})$, thus demonstrating a state of insulin resistance.

The effect of pregnancy on insulin receptor and IR S-1 phosphorylation in rat muscle. Figure $1 \mathrm{~A}$ illustrates the protocol for assessing insulin receptor signalling in the intact rat. Control and pregnant rats were injected with saline or insulin and after $90 \mathrm{~s}$ hindlimb skeletal muscle was removed and homogenized as described in $M$ ethods. The extracts were then submitted to SD S-PA GE under reducing conditions and were blotted onto nitrocellulose membranes. These blots were subsequently analysed using anti-insulin receptor, anti-IR S-1, anti-PI 3-kinase and antiphosphotyrosine antibodies.

In pregnant rats, there were no changes in the insulin receptor levels in muscle as shown by immunoblotting with an antibody to the $\mathrm{COOH}$ terminus of the insulin receptor (Figs. $1 B$ and $2 \mathrm{~A}$ ). In contrast, the levels of IR S-1 protein in muscle detected by immunoblotting were reduced by $56 \pm 0.9 \%(p<0.002)$ in pregnant rats (Figs. $1 \mathrm{C}$ and $2 \mathrm{~A}$ ).

Following in vivo stimulation with insulin, a phosphotyrosine band of $95 \mathrm{kDa}$, previously identified
A Anti-pTyr

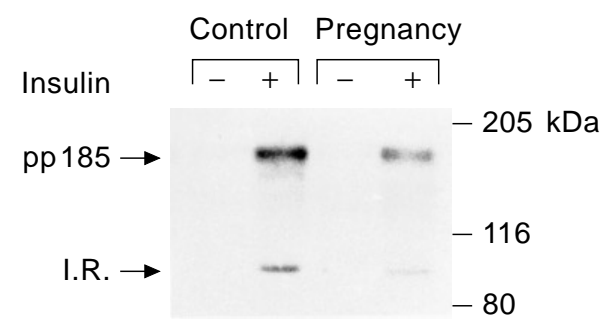

B Anti-insulin receptor antibody

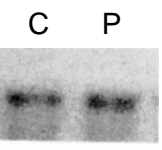

C Anti-IRS-1 antibody

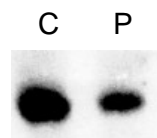

Fig. 1A -C. Insulin-stimulated tyrosine phosphorylation in the muscle of pregnant rats. R ats were anaesthetized and the abdominal wall incised to expose the viscera. $0.9 \% \mathrm{NaCl}$ (lanes 1 and 3, left to right) or $10^{-5} \mathrm{~mol} / \mathrm{l}$ insulin (lanes 2 and 4) was administered into the portal vein as a bolus injection and $90 \mathrm{~s}$ later a muscle fragment was excised and homogenized in extraction buffer $\mathrm{A}$ at $100^{\circ} \mathrm{C}$ as described in M ethods. A fter centrifugation, aliquots containing the same amount of protein were resolved by SD S-PA GE on $6 \%$ gels, transferred to nitrocellulose, and detected with antiphosphotyrosine antibody (A), anti-insulin receptor antibody (B), or anti-I R S-1 antibody (C), and [125I]protein A, and then subjected to autoradiography

as the $\beta$-subunit of the insulin receptor, appeared and became prominently phosphorylated. The level of phosphorylation of this band was reduced by $30 \pm 6 \% \quad(p<0.02)$ in pregnant rats (Figs. $1 A$ and $2 B$ ). In the same antiphosphotyrosine blots of whole tissue extracts, in addition to the $95 \mathrm{kD}$ a band seen after insulin injection, a broad band migrating between 165 and $185 \mathrm{kD}$ a was also detectable. This band is known as pp185 and contains IR S-1 as one of its components [8-11]. The phosphorylation of pp185 was reduced by $48 \pm 5 \% \quad(p<0.002)$ in pregnant animals (Figs. $1 \mathrm{~A}$ and $2 \mathrm{~B}$ )

In samples from muscle previously immunoprecipitated with anti-IRS-1 antibody and immunoblotted with antiphosphotyrosine antibody, there was a clear decrease in insulin-stimulated IR S-1 phosphorylation to $30 \pm 9 \%$ of the control value $(p<0.01)$ in pregnant rats (Figs. $2 \mathrm{C}$ and $3 \mathrm{~A}$ ). I n order to investigate the stoichiometry of IRS-1 phosphorylation (phosphate to protein ratio), we stripped these nitrocellulose 
A Protein

B Phosphorylation

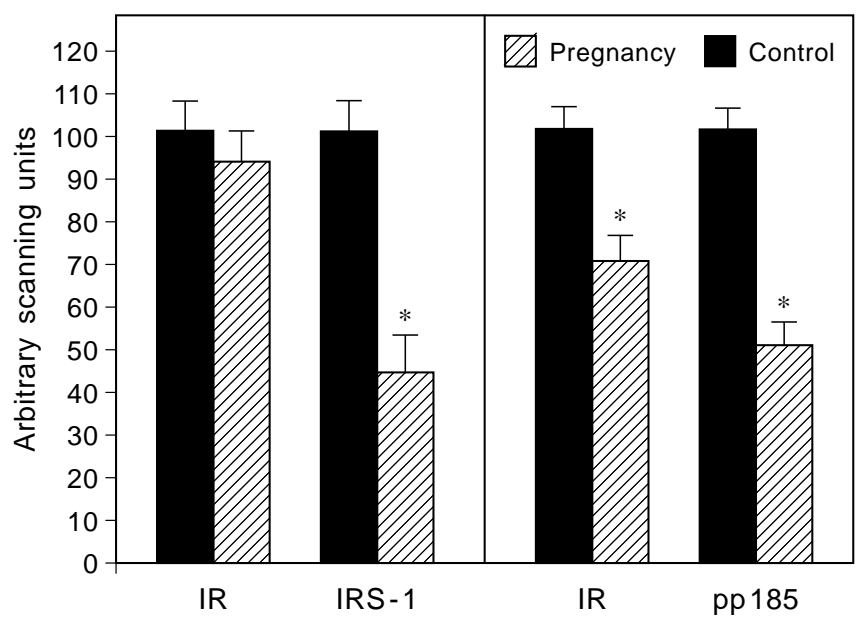

C Phosphorylation

D Association

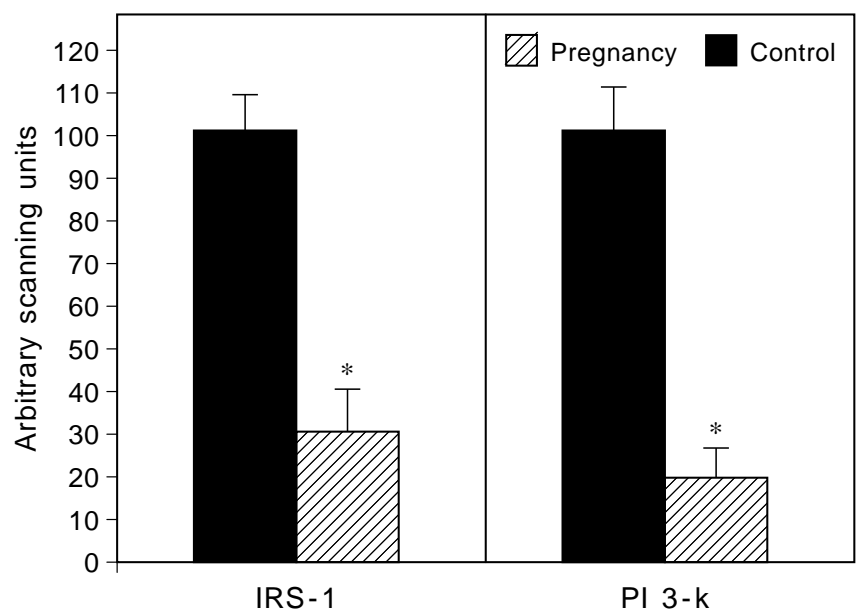

Fig. 2A - D. Insulin receptor (IR) and IR S-1 protein levels (A) and tyrosine phosphorylation of IR and pp185 (B) in the muscle of virgin and pregnant rats. Scanning densitometry was performed on autoradiograms of eight experiments for insulin receptor and IR S-1 concentrations, and seven experiments for tyrosine phosphorylation levels of IR and pp185. IR S-1 tyrosine phosphorylation levels $(\mathbf{C})$ and association with $\mathrm{PI}$ 3-kinase in muscle of virgin and pregnant rats (D). Scanning densitometry was performed on autoradiograms of four experiments for IR S-1 phosphorylation levels and four experiments for the association between IR S-1 and PI 3-kinase. D ata are expressed as mean \pm SE M and are normalized for protein content. $* p<0.05$

membranes and incubated them with anti-IR S-1 antibody, after which the phosphorylation of IR S-1 relative to the total amount of IR S-1 was calculated. Following insulin stimulation this stoichiometry was reduced by approximately $35 \%$ in the muscle of pregnant rats $(n=4)$.

Previous studies [19-23] have suggested that there is a relatively stable, high affinity interaction between IRS- 1 and the 85 kD a subunit of PI 3-kinase, such that both proteins are co-precipitated by antibodies
A Anti-pTyr

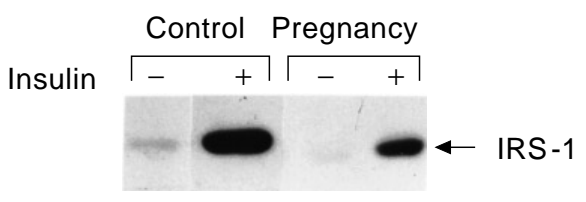

B Anti-p85

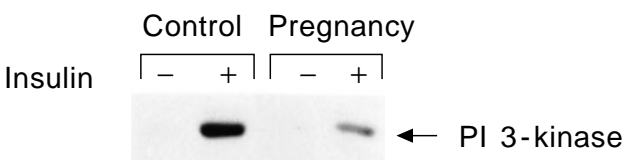

Fig. 3A, B. Insulin-stimulated tyrosine phosphorylation of IR S-1 and its association with PI 3-kinase in the muscle of virgin and pregnant rats. The proteins were isolated with extraction buffer B, as described in M ethods, and kept on ice. A fter centrifugation, aliquots of the supernatant were immunoprecipitated with anti-IR S-1 antibody and immunoblotted with antiphosphotyrosine (A) and anti-PI 3-kinase (85 kDa subunit) (B) antibodies and [ $\left.{ }^{125} \mathrm{I}\right]$ protein $\mathrm{A}$, and then subjected to autoradiography

to each protein. In samples from muscle previously immunoprecipitated with anti-IRS-1 antibody and immunoblotted with antibodies directed against the $85 \mathrm{kD}$ a subunit of PI 3-kinase, there was little or no detectable PI 3-kinase immunoreactivity in the basal state in either virgin or pregnant rats (Fig. 3B ). A fter stimulation with insulin, a band with the expected molecular weight of the regulatory subunit of PI 3-kinase ( $85 \mathrm{kD}$ a) was present in anti-IR S-1 antibody immunoprecipitates of muscle from both groups of animals. This observation is consistent with the existence of a stable complex between IR S-1 and PI 3-kinase. H owever, the amount of PI 3-kinase associated with IR S-1 was reduced by $81 \pm 6 \%(p<0.01)$ in pregnant rats (Figs. 2D and 3B), thus suggesting a reduced affinity between these two proteins. IRS-1 can also bind and activate other proteins including the phosphotyrosine phosphatase SH PTP2 [30-34]. We next investigated whether there is any change in IR S-1/ SH PT P 2 interaction during pregnancy, by performing immunoprecipitation with anti-IRS-1 antibody and immunoblotting with antibodies directed against SH PTP2. A fter stimulation with insulin, SH PTP2 is co-precipitated with IR S-1, but this association is reduced approximately $50 \%(n=3)$ in the muscle of pregnant rats (data not shown).

The effect of pregnancy on insulin receptor and IR S-1 phosphorylation in rat liver: Pregnancy had a similar effect on insulin receptor and IR S-1 phosphorylation in liver as in muscle (Fig. 4A). There was no change in the hepatic insulin receptor level as determined by immunoblotting (Fig. 4B). The immunoblotting of 
A Anti-pTyr

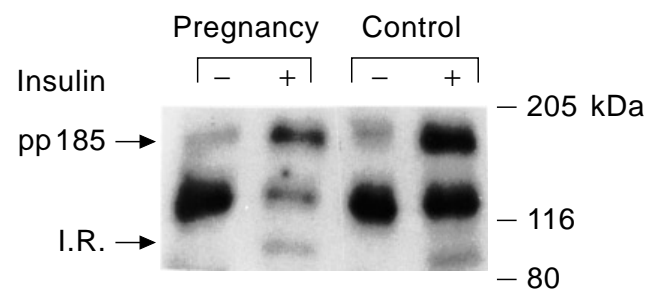

B Anti-insulin receptor antibody

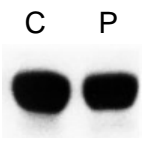

C Anti-IRS-1 antibody

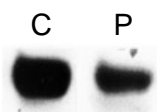

Fig. 4A - C. Insulin-stimulated tyrosine phosphorylation in the liver of pregnant rats. $R$ ats were anaesthetized and the abdominal wall incised to expose the viscera. Normal saline (lanes 1 and 3 , left to right) or $10^{-5} \mathrm{~mol} / /$ insulin (lanes 2 and 4 ) was administered into the portal vein as a bolus injection and $30 \mathrm{sla}$ ter a liver fragment was excised and homogenized in extraction buffer $\mathrm{A}$ at $100^{\circ} \mathrm{C}$ as described in Methods. A fter centrifugation, aliquots containing the same amount of protein were resolved by SD S-PA GE on $6 \%$ gels, transferred to nitrocellulose, and detected with antiphosphotyrosine antibody (A), anti-insulin receptor antibody (B), or anti-IRS-1 antibody (C), and [125I ]protein A, and then subjected to autoradiography

liver extracts with antibodies to IR S-1 revealed that the level of IR S-1 decreased by $45 \pm 6 \% \quad(p<0.002)$ in pregnant rats compared to virgin rats (Fig. $4 \mathrm{C}$ and $5 A$ ).

A fter insulin treatment, insulin receptor phosphorylation was reduced by $36 \pm 5 \% \quad(p<0.01$; Figs. $4 A$ and $5 B$ ) while the tyrosine phosphorylation of pp185 decreased by $58 \pm 8 \%(p<0.002 ;$ Figs. $4 A$ and $5 B)$ in the pregnant rats compared to the controls.

To define better the levels of IR S-1 phosphorylation, we performed Western blot analysis of tyrosylphosphorylated proteins in anti-IR S-1 immunoprecipitates before and after stimulation with insulin in both groups of animals. Figures $6 \mathrm{~A}$ and $5 \mathrm{C}$ show that there was a marked reduction ( to $25 \pm 8 \%$ of the control values; $p<0.01$ ) in insulin-stimulated IRS-1 phosphorylation in the liver of pregnant animals. When these nitrocellulose membranes were stripped and immunoblotted with anti-IR S-1, the stoichiometry of IR S-1 phosphorylation was seen to be reduced by approximately $50 \%$ in the liver of pregnant rats $(n=4)$. A ssociation of the $85 \mathrm{kD}$ a subunit of PI
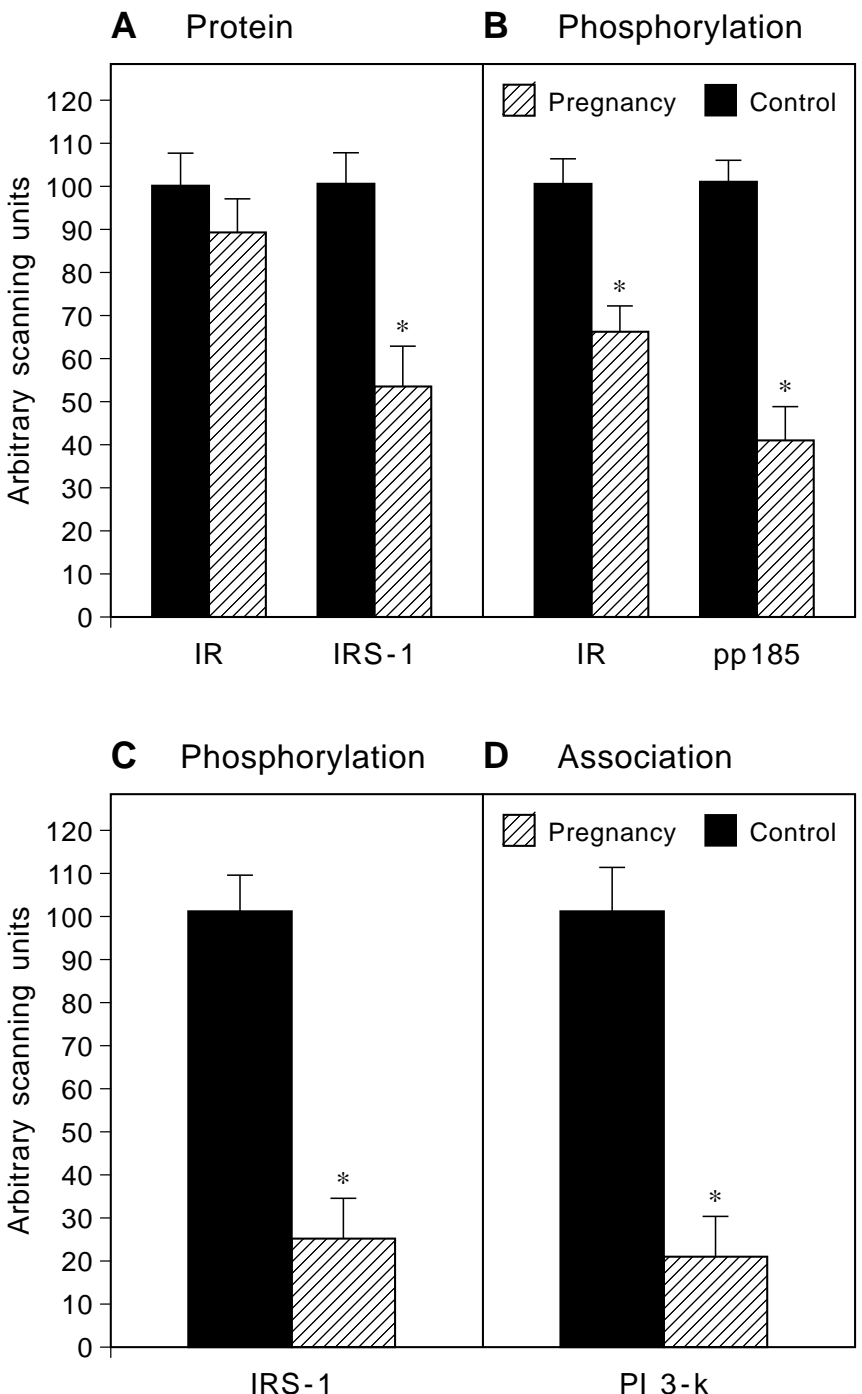

Fig. 5A - D. Insulin receptor (IR) and IR S-1 protein levels (A) and tyrosine phosphorylation of IR and pp185 (B) in the liver of virgin and pregnant rats. Scanning densitometry was performed on autoradiograms of eight experiments for insulin receptor and IRS-1 concentrations, and also for tyrosine phosphorylation levels of IR and pp185. IR S-1 tyrosine phosphorylation levels (C) and association with PI 3-kinase in liver of control and pregnant rats (D). Scanning densitometry was performed on autoradiograms of four experiments for IR S-1 phosphorylation levels and four experiments for the association between IR S-1 and PI 3-kinase. The data are expressed as the mean $\pm \mathrm{SEM}$ and are normalized for protein content. $* p<0.05$

3-kinase with IR S-1 was examined by incubating the same blot with antibodies to this subunit (Fig.6B). A s expected, in both groups, a band of $85 \mathrm{kD}$ a was present in the IR S-1 immunoprecipitates after exposure to insulin, although there was a $79 \pm 11 \%$ $(p<0.01)$ decrease in the intensity of this band in pregnant rats (Fig. 5D ). This suggests that in pregnant rats there is a reduced association between hepatic IR S-1 and PI 3-kinase after insulin stimulation. It is interesting that in liver the association of IR S-1/PI 
A Anti-pTyr

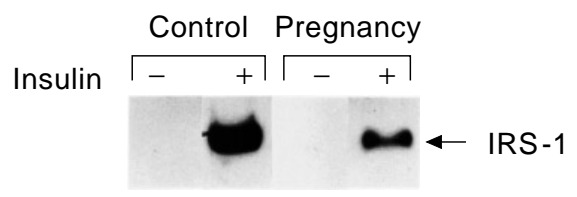

B Anti-p85

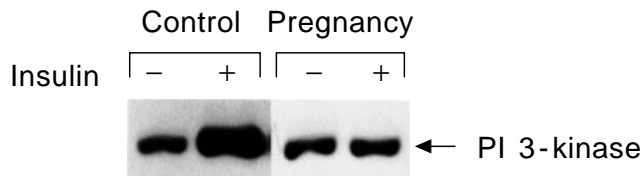

Fig.6A, B. Insulin-stimulated tyrosine phosphorylation of IR S-1 and its association with PI 3-kinase in the liver of virgin and pregnant rats. The proteins were isolated with extraction buffer B as described in Methods, and kept on ice. A fter centrifugation, aliquots of the supernatant were immunoprecipitated with anti-IR S-1 antibody and immunoblotted with antiphosphotyrosine (A) and anti-PI 3-kinase ( $85 \mathrm{kD}$ a subunit) (B) antibodies and [125I]protein A, and then subjected to autoradiography

3-kinase in the basal state is higher than in muscle both of virgin and pregnant rats. When we compared liver and muscle in both groups of animals, the IR S1 and PI 3-kinase protein levels were higher in the former. The amount of insulin reaching the liver under basal conditions is higher than in muscle, and this may enhance the association of p85 with IR S-1 in this organ. The association of IR S-1 with SH PTP2 after insulin stimulation, determined by immunoprecipitation with anti-I R S-1 antibody and immunoblotting with SH PTP2 antibody, was reduced to approximately $45 \% \quad(n=3)$ in the liver of pregnant rats (data not shown).

\section{Discussion}

In the present study, we investigated the importance of insulin receptor and IRS-1 phosphorylation and of the association of PI 3-kinase with IR S-1 in the liver and muscle of pregnant rats. It is known that pregnancy induces marked insulin resistance [1-7] and that it is accompanied by a reduced glucose uptake in peripheral tissues and an increase in hepatic glucose output. $O$ ur results indicate that pregnancy has no significant effect on the levels of the insulin receptor in rat liver and muscle. D espite the normal number of receptors, there was a $36 \%$ reduction in insulin receptor autophosphorylation in the liver and a 30\% reduction in muscle after stimulation with insulin. The phosphorylation of IR S-1 (reflecting the kinase activity of the insulin receptor towards its endogenous substrate) was reduced by $75 \%$ in the liver and by $70 \%$ in the muscle of pregnant rats. The reduction in IR S-1 protein levels may have a role in the decrease in insulin-stimulated IR S-1 phosphorylation. H owever, the stoichiometry of IRS-1 phosphorylation was also reduced in the liver and muscle of pregnant rats, demonstrating a reduction in IR S-1 phosphorylation greater than when taking into account the decrease in IR S-1 protein. In this context, changes in the insulin receptor kinase in the same direction may have at least a permissive role, since the IR S-1 protein levels are not the only determinant of IR S-1 phosphorylation levels [35, 36]. Whether these regulatory defects induced by chronic hyperinsulinaemia reflect alterations in receptor and IR S-1 serine phosphorylation or some other regulatory event is unknown. Interestingly, the amount of PI 3kinase associated with IR S-1 was also reduced in the liver and muscle of these animals. The decrease in the three early steps of insulin action after hormone binding may have an important role in the insulin resistance observed during pregnancy. Insulin increases glucose uptake into cells, partly through the translocation of GLUT4 from intracellular compartments to the plasma membrane in muscle and adipose tissues [37]. D istinct experimental approaches have led to the conclusion that PI 3-kinase is necessary for insulin-stimulated G L UT 4 translocation [38-44]. E vidence from other sources has also demonstrated a correlation between PI 3-kinase activity and glycogen metabolism [45, 46]. Thus, it is reasonable to speculate that the IRS-1/PI 3-kinase pathway may be linked to the activation of glucose transport in muscle and glycogen synthesis in liver and muscle, and that a reduction in this association in pregnancy may have a role in the insulin resistance in liver and muscle of pregnant rats.

In addition to $\mathrm{PI}$ 3-kinase other $\mathrm{SH} 2$ proteins, including N ck, G R B 2 [8] and SH PTP2 (also known as Syp and phosphotyrosine phosphatase 1D) [30-34] were found to associate with IR S-1. The association of SH PTP2 with IR S-1 may activate the phosphatase, in a manner analogous to the activation of PI 3-kinase $[30,31]$. R ecent data suggest that SH PT P 2 has a role in insulin-stimulated mitogenesis and also indicate that this phosphatase is necessary for insulin-stimulated expression of GLUT1 [32]. There is evidence that SH PTP2 can dephosphorylate IR S-1 [30, 31], although this has not been uniformly observed [33, 34]. O ur results showed that the association of IR S1/SH PT P2 after insulin stimulation was also reduced in the liver and muscle of pregnant rats, suggesting that alterations in this association do not account for the reduction in IR S-1 phosphorylation in these animals. Instead, the decrease in IR S-1/SH PT P2 interaction in pregnant rats may reflect a reduction in IR S-1 phosphorylation.

The mechanisms whereby pregnancy induces the above alterations are unknown but the hormonal 
milieu may have a role. A $n$ increase in circulating hormones such as progesterone and placental lactogen, which act as antagonists of insulin, may contribute to insulin resistance during pregnancy. In this regard, maternal plasma corticosterone levels are increased on day 18 and remained high until parturition [47]. H owever, the influence of progesterone and placental lactogen on the early steps of insulin action have not yet been investigated. The effect of an excess of glucocorticoid on these steps is well established in the liver and muscle of animals [36, 48], and also in cell culture [49]. In animals treated with dexamethasone, there is a decrease in insulin receptor and IRS-1 phosphorylation in the liver, and a decrease in PI 3-kinase activity in both liver and muscle. Interestingly, there is also a decrease in the IR S-1 protein levels in muscle [36, 48]. In 3T 3-F 442A adipocytes, the administration of dexamethasone reduced the insulin receptor and IR S-1 tyrosine phosphorylation levels as well as PI 3-kinase activity [49]. Taken together, these findings suggest that high cortisol levels may have a role in the alterations seen in the early steps of insulin action in these rats. $\mathrm{H}$ yperinsulinaemia per se can also induce similar alterations in early steps of insulin action, as demonstrated in previous studies of animal models of insulin resistance and in cell culture [35, 49, 50]. H owever, as the insulin levels observed in pregnant rats are only slightly higher than in virgin animals, this increase may not be responsible for all of the observed effects.

In summary, this study has shown that a reduced expression and/or phosphorylation of IRS-1 may lead to reduced association between IR S-1/PI 3-kinase in the liver and muscle of pregnant rats. These data suggest that changes in the early steps of insulin action may have a role in the insulin resistance observed in these animals.

A cknowledgements. The authors wish to thank Drs. C.R. K ahn, M . F. White and M. M yers (J oslin Diabetes Center) for kindly providing anti-insulin receptor and anti-IR S-1 antibodies, and also M r. L. Janeri and M s. C. da Silva for technical assistance. This work was supported by grants from FA PESP and CNPq.

\section{References}

1. Ryan EA, O'Sullivan MJ, Skyler J S (1985) Insulin action during pregnancy. D iabetes 34: 380-389

2. Ciaraldi TP, K ettel M, E L-R oeiy A, M adar Z, R eichart D, Yen SSC, O lefsky J M (1994) M echanisms of cellular insulin resistance in human pregnancy. A m J O bstet G ynecol 170: 635-641

3. Schmon B, D esoye G, Friedl H, H ofmann H, Weiss PA M, Hagmüller K (1993) Insulin receptor binding to erythrocytes in the first half of pregnancy is increased in healthy pregnant women as compared with non-pregnant or gestational diabetic women. Clin Chim A cta 22: 33-46

4. D amm P, H andberg A, Kuhl C, B eck-N ielson $H$, M olstedPedersen L (1993) Insulin receptor binding and tyrosine ki- nase activity in skeletal muscle from normal pregnant women and women with gestational diabetes. O bstet $\mathrm{G}$ ynecol 82: 251-259

5. L eturque A, B urnol A F, Ferre P, G irard J (1984) Insulin resistance in pregnant rats. A m J Physiol 246:E 25-E 31

6. L eturque A, Ferre P, B urnol A F, K ande J, M aulard P, G irard J (1986) In vivo glucose utilization rates and insulin sensitivity in tissues of pregnant rats. Diabetes 35: 172-177

7. Leturque A, Burnol A F, Ferre P, Girard J (1984) Pregnancy-induced insulin resistance in the rat: assessment by glucose clamp technique. A m J Physiol U SA 246:E 25-E 31

8. White M F, Kahn CR (1994) The insulin signaling system. J Biol Chem 269: 1-5

9. White M F, M aron R, K han CR (1985) Insulin rapidly stimulates tyrosine phosphorylation of a $M_{r} 185,000$ protein in intact cells. Nature 318: 183-186

10. $R$ othenberg PL, L ane WS, K arasik A, B acker J, White M F, K ahn CR (1991) Purification and partial sequence analysis of pp185, the major cellular substrate of insulin receptor tyrosine kinase. J Biol Chem 266: 8302-8311

11. Sun XJ, R othernberg PL, Kahn CR et al. (1991) Structure of the insulin receptor substrate IR S-1 defines a unique signal transduction protein. Nature 352: 73-77

12. M aegawa $H$, O lefsky J M , Thies S, B oyd D, U IIrich A, M cClain DA (1988) Insulin receptor with defective tyrosine kinase inhibits normal receptor function at the level of substrate phosphorylation. J Biol Chem 263: 12629-12637

13. E bina $Y$, A raki E , Taira M et al. (1987) R eplacement of lysine residue 1030 in the putative A TP-binding region of the insulin receptor abolishes insulin- and antibody-stimulated glucose uptake and receptor kinase activity. Proc Natl A cad Sci U SA 84: 704-708

14. M omomura $K$, Tobe $K$, Seyama $Y$, Takaku $F, A$ kanuma $Y$, K asuga M (1987) Insulin-induced tyrosine phosphorylation in intact rat adipocytes. Biochem Biophys R es Commun 155: 1181-1186

15. Chou CK, D ull TJ , R usse DS, G herzi R, L ewohl D, U Ilrich $A$, R osen OM (1987) H uman insulin receptors mutated at the A TP-binding site lack protein tyrosine kinase activity and fail to mediate postreceptor effects of insulin. J Biol Chem 262: 1842-1847

16. Sun X J, M iralpeix M , M yers M G, J r, G lasheen E M , B acker J M , K ahn CR, White M F (1992) Expression and function of IR S-1 in insulin signal transmission. J Biol Chem 267: 22662-22672

17. Wang LM, Keegan A D, Li W et al. (1993) Common elements in IL 4 and insulin signaling pathways in factor dependent hemapotopoietic cells. Proc Natl A cad Sci U SA 90: 4032-4036

18. Saad M JA, Velloso LA , Carvalho CR O (1995) A ngiotensin II induces tyrosine phosphorylation of insulin receptor substrate 1 and its association with phosphatidylinositol 3-kinase in rat heart. Biochem J 310: 741-744

19. K elly KL, Ruderman NB (1993) Insulin-stimulated phosphatidylinositol 3-kinase. A ssociation with a 185-kD a tyrosine-phosphorylated protein (IR S-1) and localization in a low density membrane vesicle. J Biol Chem 268: 43914398

20. G iorgetti S, B alloti R, Kowaiski-Chawel A, Tartare S, Van O berghen E (1993) The insulin and insulin-like growth factor- 1 receptor substrate IR S-1 associates with and activates phosphatidylinositol 3-kinase in vitro. J Biol Chem 269: 7358-7364

21. Backer J M, M yers M G J r, Schoelson SE et al. (1992) The phosphatidylinositol 3-kinase is activated by association with IR S-1 during insulin stimulation. E M BO J.11: 34693479 
22. $L$ amphere $L, C$ arpenter $C L$, Sheng $Z F$, K allen $R G$, L ienhard GE (1994) A ctivation of PI 3-kinase in 3T 3-L 1 adipocytes by association with insulin receptor substrate-1. A $\mathrm{m} \mathrm{J}$ Physiol E 486-E 494

23. Folli F, Saad M JA, Backer J M, Kahn CR (1992) Insulin stimulation of phosphatidylinositol 3-kinase activity and association with IR S-1 in liver and muscle of the intact rat. J Biol Chem 267: 22171-22177

24. Saad M JA, H artmann LG C, Carvalho DS, Galoro CA O, B renelli SL, Carvalho CRO (1995) E ffect of glucagon on insulin receptor substrate-1 (IR S-1) phosphorylation and association with phosphatidylinositol 3-kinase (PI 3-kinase). FE B S letters 370: 131-134

25. Carvalho CRO, Brenelli SL, Silva A C, Nunes A L B, Velloso LA , Saad M JA (1996) E ffect of aging on insulin receptor, insulin receptor substrate-1, and phosphatidylinositol 3-kinase in liver and muscle of rats. Endocrinology 137: 151-159

26. Saad M JA, H artmann LGC, Carvalho D S, Galoro CA O, B renelli SL, Carvalho CRO (1995) Modulation of early steps in insulin action in the liver and muscle of epinephrine treated rats. E ndocrine 3: 755-759

27. L aemmli U K (1970) Cleavage of structural proteins during the assembly of the head of bacteriophage T 4 . N ature 227 : 680-685

28. Towbin H, Staehlin J, Gordon J (1979) Electrophoretic transfer of proteins from polyacrylamide gels to nitrocellulose sheets. Procedure and some applications. Proc Natl A cad Sci U SA 76: 4350-4354

29. B radford M M (1976) A rapid and sensitive method for the quantitation of microgram quantities utilizing the principle of protein dye binding. A nal. Biochem. 72: 248-254

30. K uhné M R , Z hao Z, R owles J, L avan BE, Shen SH, Fisher E H, Lienhard GE (1994) D ephosphorylation of insulin receptor substrate 1 by the tyrosine phosphatase PTP2C. J Biol Chem 269: 15833-15837

31. Yamauchi K, Milarski KL, Saltiel A R, Pessin JE (1995) Protein-tyrosine-phosphatase SH PTP2 is a required positive effector for insulin downstream signaling. Proc $\mathrm{N}$ atl A cad Sci U SA 92: 664-668

32. H ausdorff SF, B ennett A M , N eel B G, B irnbaum M J (1995) Different signaling roles of SHPTP2 in insulin-induced GLUT1 expression and GLUT4 translocation. J Biol Chem 270: 12965-12968

33. M ilarski KL, Saltiel A R (1994) Expression of catalytically inactiva Syp phosphatase in 3T 3 cells blocks stimulation of mitogen-activated protein kinase by insulin. J Biol Chem 269: 21239-21243

34. Nogushi T, M atozaki T, H orita K, Fujioka $Y$, Kasuga $M$ (1994) Role of SH-PTP2, a protein-tyrosine phosphatase with Src homology 2 domains, in insulin-stimulated ras activation. $\mathrm{M}$ ol Cel Biol 14: 6674-6682

35. Saad MJA, A raki E, M iralpeix $M, R$ othenberg $P L$, W hite M F, Kahn CR (1992) R egulation of insulin receptor substrate- 1 in liver and muscle of animal models of insulin resistance. J Clin Invest 90: 1839-1849

36. Saad M J A, Folli F, K ahn JA, K ahn CR (1993) Modulation of insulin receptor, insulin receptor substrate-1 and phosphatidylinositol 3-kinase in liver and muscle of dexamethasone-treated rats. J Clin Invest 92: 2065-2072
37. Stephens J M , Pilch PF (1995) The metabolic regulation and vesicular transport of GLUT4, the major insulin-responsive glucose transporter. E ndocrine R eviews 16: 529-546

38. H ara K , Y onezawa K, Sakaue H et al. (1994) Phosphoinositide 3-kinase activity is required for insulin-stimulated glucose transport but not for ras activation in $\mathrm{CHO}$ cells. Proc N atl A cad Sci U SA 91: 7415-7419

39. O kada T, Kawano Y, Sakahihara T, H azeki O, U i M (1994) E ssential role of phosphatidylinositol 3-kinase in insulin induced glucose transport and antilipolysis in rat adipocytes. Studies with a selective inhibitor wortmannin. J Biol Chem 269: 3568-3573

40. Clarke JF, Y oung PW, Y onezawa K, K asuga M, H olman GD (1994) Inhibition of the translocation of GLUTI and G L UT 4 in 3T 3-I1 cells by the phosphatidylinositol 3-kinase inhibitor, wortmannin. Biochem J 300: 631-635

41. Y eh JI, Gulve E A, R ameh L, B irbaum MJ (1995) The effects of wortmannin on rat skeletal muscle. D issociation of signaling pathways for insulin- and contraction-activated hexose transport. J Biol Chem 270: 2107-2111

42. Sanches-M argalet V, Goldfine ID, V lahos CJ, Sung CK (1994) R ole of phosphatidylinositol 3-kinase in insulin receptor signaling: studies with inhibitor LY 294002. B iochem Biophys R es Commun 204: 446-452

43. $H$ aruta $T$, M orris A J, Rose DW, N elson J G, M ueckler M, O lefsky J M (1995) Insulin stimulated G LUT 4 translocation is mediated by a divergent intracellular signaling pathway. J Biol Chem 270: 27991-27994

44. Cheathan B, V lahos C J, Chathan L, Wang L, B lenis J, K ahn CR (1994) Phosphatidylinositol 3-kinase activation is required for insulin stimulation of pp70S6 kinase, D N A synthesis, and glucose transporter translocation. Mol Cell Biol 14: 4902-4911

45. Cross DAE, A lesi DR, Vandenheede JR, Mcdowell HE, $H$ undal H S, Cohen $P$ (1994) The inhibition of glycogen synthase kinase- 3 by insulin or insulin-like growth factor 1 in the rat skeletal muscle cell line $L 6$ is blocked by wortmannin, but not by rapamycin: evidence that wortmannin blocks activation of the mitogen-activated protein kinase pathway in $L 6$ cells between $R$ as and $R$ af. B iochem J 303: 21-26

46. Welsh G I, Foulstone E J, Y oung SW, Tavaré J M , Proud CG (1994) Wortmannin inhibits the effects of insulin and serum on the activities of glycogen synthase kinase- 3 and mitogen-activated protein kinase. B iochem J 303: 15-20

47. R ushakoff RJ, Kalkhoff RK (1983) Relative effects of pregnancy and corticosterone administration on skeletal muscle metabolism in the rat. E ndocrinology 113: 43-47

48. Giorgino F, A Imahfouz A, G oodyear L, Smith RJ (1993) $G$ lucocorticoid regulation of insulin receptor and substrate IRS-1 tyrosine phosphorylation in rat skeletal muscle in vivo J. Clin I nvest 91: 2020-2030

49. Saad MJA, Folli F, A raki E, Hashimoto N, Csermely P, K ahn CR (1994) R egulation of insulin receptor, insulin receptor substrate 1 and phosphatidylinositol 3-kinase in 3T 3-F 442A adipocytes. Effects of differentiation, insulin and dexamethasone. M ol Endocrinol 8: 545-557

50. Folli F, Saad M JA, B acker J M , K ahn CR (1993) R egulation of phosphatidylinositol 3-kinase activity in liver and muscle of animal models of insulin resitance and insulin-deficient diabetes mellitus. J Clin Invest 92: 1787-1794 